\title{
Desalination of Seawater Using Lab Scale Solar Plant
}

\author{
Zahid Naeem Qaisrani**, Asadullaha, Mohammad Hashim ${ }^{\mathrm{b}}$, Syed Kamran Sami ${ }^{\mathrm{b}}$, Syed Haseeb Sultan ${ }^{\mathrm{c}}$, \\ Mohammad Siddique ${ }^{\mathrm{d}}$ \\ ${ }_{a, b, c, d}$ Department of Chemical Engineering, Balochistan University of Information Technology, Engineering and \\ Management Sciences (BUITEMS), Quetta, Pakistan \\ *Corresponding Author: engr.zbaloch@gmail.com
}

\begin{abstract}
The current study describes the desalination of sea water using solar energy with particular focus on the design and fabrication aspects for single slope solar still. The purpose of this study was to present a novel, economically feasible methodology along with the equipment to overcome the water shortage particularly in the remote areas along the coastal belt in Pakistan. In order to achieve these objectives, a laboratory scale solar still was fabricated made of galvanized iron having basin area of $5490 \mathrm{~cm}^{2}$ (length of $90 \mathrm{~cm}$ and width of $61 \mathrm{~cm}$ ), front height $15 \mathrm{~cm}$ and back height $32 \mathrm{~cm}$. The Inclined angle was kept at $\mathbf{1 5}^{\circ}$. The experiments were conducted during typical winter days. Results showed that when the highest ambient temperature was $29.9{ }^{\circ} \mathrm{C}$, the maximum value of the average solar intensity was $1,080 \mathrm{~W} / \mathrm{m}^{2}$. A remarkable decrease in terms of total suspended solids (TSS), total dissolved solids (TDS), thermal conductivity, hardness, turbidity, and $\mathrm{pH}$ was observed. The value of TDS decreased from $29,100 \mathrm{mg} / \mathrm{L}$ to $385 \mathrm{mg} / \mathrm{L}$, TSS from $0.07 \mathrm{~g} / 100 \mathrm{~mL}$ to $0.00086 \mathrm{~g} / \mathrm{mL}$, thermal conductivity from $45,500 \mu$ s to $595 \mu \mathrm{s}$, hardness $133 \mathrm{meq} / \mathrm{L}$ to $2.7 \mathrm{meq} / \mathrm{L}$, turbidity from $29.3 \mathrm{NTU}$ to $19.3 \mathrm{NTU}$, and pH from 9.36 to 6.22, respectively. Furthermore, temperature profile against the intensity was drawn to identify the peak efficient hours with highest heat intensity. The suggested technique cannot only give a solution for the domestic level use rather it can be utilized in commercial scale in solar desalination facilities.
\end{abstract}

Keywords: Renewable energy; Desalination; Fabrication; Galvanized iron

Date Received 14 May 2019

Date Accepted 11 June 2019

Date Published 5 July 2019

\section{INTRODUCTION}

Drinking water treatment is one of the burning issues in all over the world generally and in developing countries particularly. Due to economic issues in developing countries, using alternative energy to get fresh drinking water is of keen interest. Almost $97.5 \%$ of the world water resources are salt water in the form of oceans and seas. Out of the remaining, $2.5 \%$ of fresh water, $68.9 \%$ is in the form of glaciers and $30.8 \%$ as groundwater. Only $0.3 \%$ is accessible to human beings for direct use [1]. The use of water is going to increase every year due to increase in population, change in lifestyle and agricultural \& industrial activities [2]. Water scarcity in Pakistan is rapidly growing. Per capita, water availability has sharply declined from $5,600 \mathrm{~m}^{3}$ in 1947 to around $1,100 \mathrm{~m}^{3}$ for the current population of approximately 220 million. This situation will become worse with the fast-growing population and urbanization. Based on current trends, it is likely that per capita water availability will decline to around $800 \mathrm{~m}^{3}$ and $6 \%$ increase in demand will be observed by 2025 , making Pakistan a water scarce country [3]. Pakistan coastal region is mostly undeveloped and has water scarcity up to an emergency level. This problem was highlighted by scientists and researchers from time to time [4-6], but unfortunately, due to lack of resources and unavailability of technology, people of those areas are still suffering from such water shortage. Many researchers use different resources to overcome the burning issue of water shortage including wastewater treatment, rain water harvesting, desalination of sea water, grey water recycling and many more [7-10]. Various techniques have been adopted previously by researchers to clean saline water to be used for domestic applications particularly in coastal regions. Some of the most prominent techniques are membrane desalination [11], solar membrane distillation desalination [12], Vacuum membrane solar desalination [13]. All methods have their own importance but the location and availability of technology is of key concern which seems to be a major problem in these areas. Apart from this, such technology needs a big capital which is indeed another problem for Government stakeholders. Considering mentioned drawbacks being cost effective with ease of operation utilizing solar energy and a well-designed solar still can be very effective to overcome this issue in these particular regions. Design of a solar still to get fresh water can solve water shortage in coastal regions [14]. Desalination is one of the growing technologies specially in coastal areas and water scarce countries [15].

Current study aims to develop a solar still using galvanized iron and the aluminium sheet is used to heat up and desalinate the sea water [16]. The water samples were taken from the sea near Karachi, 
Pakistan and stored in the big storage tanks. The water from storage tank was sent to the solar still. The rise in water temperature due to solar energy tends to start evaporation; thereby rise to the glass cover and condensed on the tilted glass. The condensed water was collected in the collecting trough and then sent to the collecting tank. The temperature of aluminium sheet, glass, and water was noted using the probe sensors connected to the digital thermometer fixed in a panel after every $30 \mathrm{~min}$ interval up to $7 \mathrm{hrs}$. The experiments were repeated in a similar manner for three consecutive days. The capacity of the feed tank was 25 litres. The maximum temperature of water achieved during this experiment was $40.8^{\circ} \mathrm{C}$ at 1600 hrs PST.

\section{MATERIALS AND METHODOLOGY}

\section{A. Materials and Instrumentation}

To fabricate the solar still galvanized iron sheets were purchased from local iron sheet supplier present in Quetta, Pakistan. Aluminium alloy sheets of food grade quality were purchased from Prime Aluminium, Lahore, Pakistan. The temperature was measured by means of the digital thermometer (CLEGK2 Legionella Temp Kit Integral Timer+ KS01-S Probe) connected with $\mathrm{K}$ type temperature probes. Other sampling and analysis were conducted using instruments such as TDS, Conductivity meter, turbidity, hardness, and $\mathrm{pH}$ meter were from Mettler Toledo present at Faculty of Engineering, Balochistan University of Information Technology, Engineering and Management science, Quetta, Pakistan.

\section{B. Methodology}

Water samples were collected from an industrial saline water sample collection point at Hawke's Bay beach near Karachi, Pakistan. Initially, the natural properties (TSS, TDS, thermal conductivity, turbidity, hardness and $\mathrm{pH}$ ) of the water sample were calculated in order to compare the results after the solar treatment. The single slope solar still was fabricated in the way to use direct solar energy in order to save conventional energy. Solar still used in this study was made front height $15 \mathrm{~cm}$ and back height $32 \mathrm{~cm}$ shown in Figure 1. The inclined angle was kept at $15^{\circ}$. The solar distiller was made up of a thermally insulated basin with all sides locked and has a glass cover (Figure 1). The glass cover is normally slanted in order to allow vapor condensation over it to drip down along a side conduit and then to a trough for collecting pure water. Transparent Glass was fixed at the top of the still with silicon, having an area of $5760 \mathrm{~cm}^{2}$. The basin was made of galvanized iron having basin area of $5490 \mathrm{~cm}^{2}$ (length of $90 \mathrm{~cm}$ and width of $61 \mathrm{~cm}$ ). Aluminium sheet was placed at the bottom of still having an area of $5340 \mathrm{~cm}^{2}$. Styrofoam was used for the insulation of still to prevent heat losses. Usually, the bottom of the basin is coated with black paint or any other suitable coating materials in order to increase the absorption rate of sun radiation [17]. To check the temperature of the glass, water and Aluminium sheet separately, three digital thermometers were used. The probes of these thermometers were fixed with glass, water, and aluminium sheet to calculate the individual temperatures. Water inlet point was made at the top and collection after desalination treatment was made at outlet discharge at the bottom basin. To identify the peak heat intensity time and duration the temperature profile were made from 1030 to $1640 \mathrm{hrs}$ PST. The experiments were conducted for three consecutive days during winter to get better results.

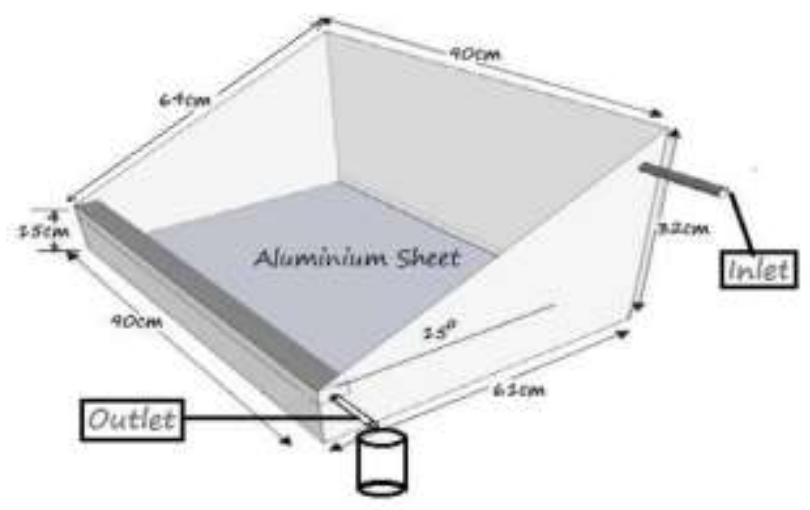

Figure 1. Fabrication of material for desalination of sea water using direct solar energy

\section{RESULTS AND DISCUSSIONS}

The temperature of the glass, water, and Aluminium sheet was of keen interest and calculated values are shown in Table 1 for the first day, Table 2 for the second day and in Table 3 for the third day of the experiments. A significant change was noted in TSS, TDS, thermal conductivity, hardness, turbidity and $\mathrm{pH}$ of the water before and after desalination shown in Table 4. The water obtained after the desalination process was directly recommended for drinking purpose. It is recommended to use direct solar energy to get the required results by saving conventional energy. It was noted that with ambient temperature 35$55^{\circ} \mathrm{C}$, the production will increase by $16-30 \%$. Use of reflectors can increase the efficiency of solar still. Also, the duration of sunlight is longer in summer as compared to the winter season in Pakistan to get better and efficient results during summer [18]. It was noticed that maximum temperature $\left(40.8{ }^{\circ} \mathrm{C}\right)$ of the water during desalination was achieved at $1600 \mathrm{hrs}$ PST. This 
temperature with a little drop was consistent between 1530 to $1730 \mathrm{hrs}$. Therefore, ideally, it is suggested to adopt peak hours for sun intensity.

Table 1Calculated temperature of Glass, Water, and Aluminium Sheet for the $1^{\text {st }}$ day

\begin{tabular}{ccccc}
\hline S.No. & Time & $\begin{array}{c}\text { TG } \\
\left({ }^{\circ} \mathbf{C}\right)\end{array}$ & $\begin{array}{c}\text { Tw } \\
\left({ }^{\circ} \mathbf{C}\right)\end{array}$ & $\begin{array}{c}\text { TA } \\
\left({ }^{\circ} \mathbf{C}\right)\end{array}$ \\
\hline 1 & $10: 30$ & 16.5 & 17.1 & 35 \\
2 & $11: 00$ & 17.8 & 17.9 & 36.7 \\
3 & $11: 30$ & 20 & 20 & 40.5 \\
4 & $12: 00$ & 21.3 & 23.2 & 43.6 \\
5 & $12: 30$ & 23.4 & 25.4 & 46.4 \\
6 & $13: 00$ & 22.7 & 28 & 49.5 \\
7 & $13: 30$ & 24.6 & 30.2 & 51.9 \\
8 & $14: 00$ & 22.5 & 31.9 & 54 \\
9 & $14: 30$ & 24.2 & 33.5 & 56.5 \\
10 & $15: 00$ & 25.9 & 34.4 & 58.1 \\
11 & $15: 30$ & 24.5 & 35 & 58.3 \\
12 & $16: 00$ & 23.5 & 34.9 & 57.9 \\
13 & $16: 30$ & 22.7 & 34.1 & 57.2 \\
14 & $17: 00$ & 18.4 & 32.9 & 55 \\
15 & $17: 30$ & 13.9 & 31 & 52.4 \\
\hline
\end{tabular}

Table 2. The calculated temperature of Glass, Water and Aluminium Sheet for 2nd day

\begin{tabular}{ccccc}
\hline S.No. & Time & $\begin{array}{c}\text { TG } \\
\left({ }^{\circ} \mathbf{C}\right)\end{array}$ & $\begin{array}{c}\text { Tw } \\
\left({ }^{\circ} \mathbf{C}\right)\end{array}$ & $\begin{array}{c}\text { TA } \\
\left({ }^{\circ} \mathbf{C}\right)\end{array}$ \\
\hline 1 & $10: 30$ & 15.2 & 18.9 & 38.5 \\
2 & $11: 00$ & 17 & 18.9 & 39.6 \\
3 & $11: 30$ & 19.2 & 20.4 & 41.4 \\
4 & $12: 00$ & 19.8 & 21.2 & 43.2 \\
5 & $12: 30$ & 22.4 & 23.6 & 46.6 \\
6 & $13: 00$ & 24.6 & 26.6 & 49.1 \\
7 & $13: 30$ & 25.2 & 29 & 52.1 \\
8 & $14: 00$ & 28.5 & 31.3 & 54.9 \\
9 & $14: 30$ & 29.2 & 33.5 & 57.2 \\
10 & $15: 00$ & 29.8 & 35.3 & 59.4 \\
11 & $15: 30$ & 29.5 & 36.4 & 60.5 \\
12 & $16: 00$ & 29.9 & 37.5 & 62.1 \\
13 & $16: 30$ & 29.2 & 37.5 & 62 \\
14 & $17: 00$ & 26.2 & 36.7 & 61.6 \\
15 & $17: 30$ & 26.2 & 36.1 & 60.2 \\
\hline
\end{tabular}

Table 3. The calculated temperature of Glass, Water and Aluminium Sheet for 3rd day

\begin{tabular}{ccccc}
\hline S.No. & Time & $\begin{array}{c}\text { TG } \\
\left({ }^{\circ} \mathbf{C}\right)\end{array}$ & $\begin{array}{c}\text { Tw } \\
\left({ }^{\circ} \mathbf{C}\right)\end{array}$ & TA $\left({ }^{\circ} \mathbf{C}\right)$ \\
\hline 1 & $10: 30$ & 17.8 & 19.5 & 39.2 \\
2 & $11: 00$ & 22.3 & 20.3 & 40.8 \\
3 & $11: 30$ & 25.7 & 22.8 & 43.4 \\
4 & $12: 00$ & 25.2 & 24.2 & 46.4 \\
5 & $12: 30$ & 27.4 & 27.1 & 50.1
\end{tabular}

\begin{tabular}{ccccc}
6 & $13: 00$ & 29.5 & 30.5 & 52.1 \\
7 & $13: 30$ & 31.4 & 33.3 & 56.1 \\
8 & $14: 00$ & 30.8 & 34.9 & 58.4 \\
9 & $14: 30$ & 31.6 & 37.1 & 62 \\
10 & $15: 00$ & 33.1 & 38.4 & 64 \\
11 & $15: 30$ & 32.3 & 39.4 & 65.5 \\
12 & $16: 00$ & 32.9 & 40.3 & 66 \\
13 & $16: 30$ & 35.3 & 40.8 & 68.8 \\
14 & $17: 00$ & 34.1 & 40.7 & 66.4 \\
15 & $17: 30$ & 29.9 & 40 & 65.4 \\
\hline
\end{tabular}

Table 4. Properties of water samples before and after the desalination process

\begin{tabular}{ccc}
\hline Parameters & $\begin{array}{c}\text { Before } \\
\text { Process }\end{array}$ & $\begin{array}{c}\text { After } \\
\text { Process }\end{array}$ \\
\hline TSS (mg/l) & 29100 & 385 \\
TDS (g/100ml) & 0.04 & 0.00086 \\
Thermal & & \\
Conductivity ( $\mu$ s) & 45500 & 595 \\
Hardness (meq/l) & 133 & 2.7 \\
Turbidity (NTU) & 29.3 & 19.3 \\
pH & 9.36 & 6.22 \\
\hline
\end{tabular}

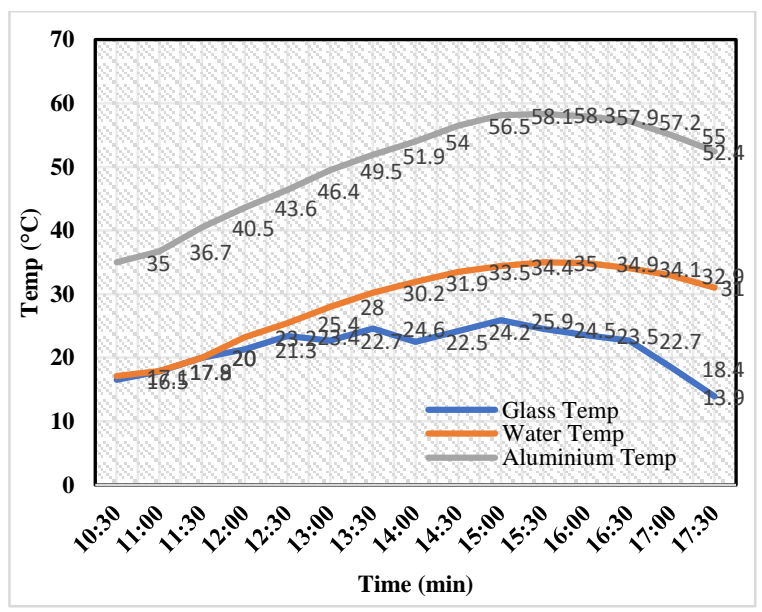

Figure 2. The temperature of Glass, water and Aluminium sheet with respect to time for the 1 st day of the experiment 


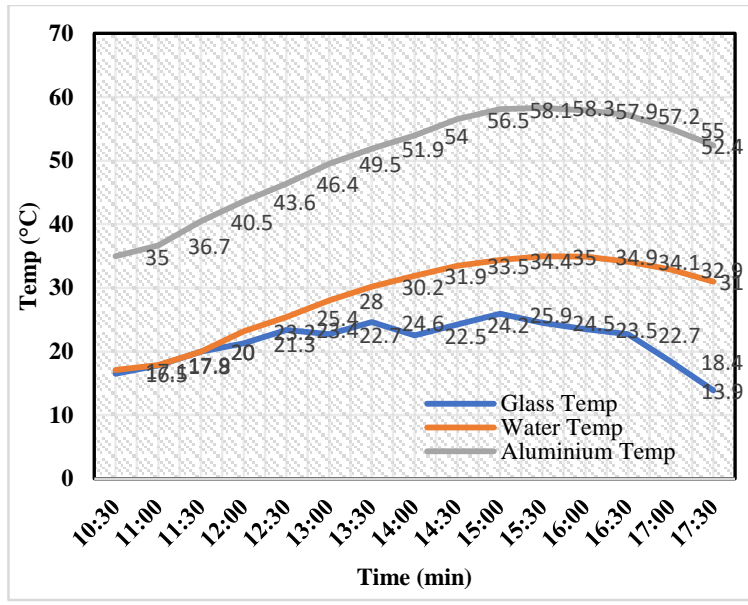

Figure 2 shows a quicker increase rate of temperature in the aluminium sheet as compare to glass temperature. This change is due to the thermal conductivity of the material. Aluminium sheet exhibits an increased rate of temperature profile to retain the temperature of water. From

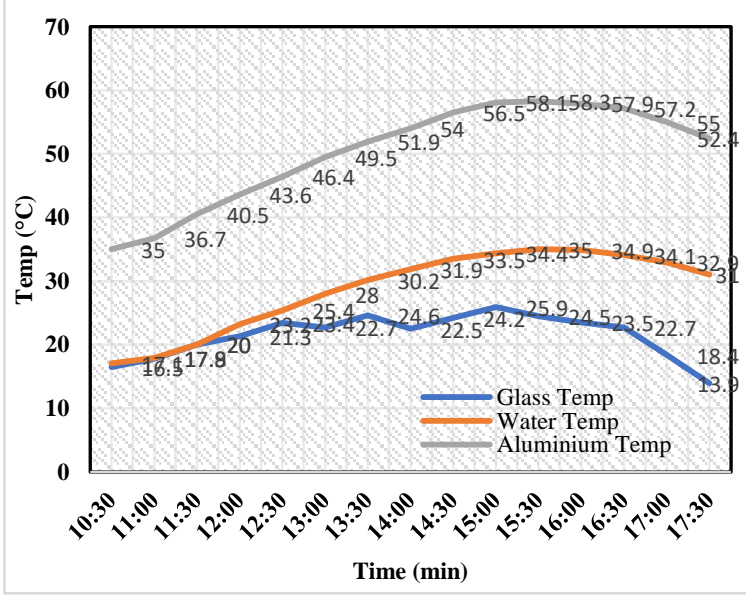

Figure 2,

Figure 3 and

Figure 4 it can be observed that an increase in temperature is noted from 1 P.M to 4 P.M then slight decrease was seen. Small variation in water temperature was also recorded, that was perhaps due to the delay in convection.

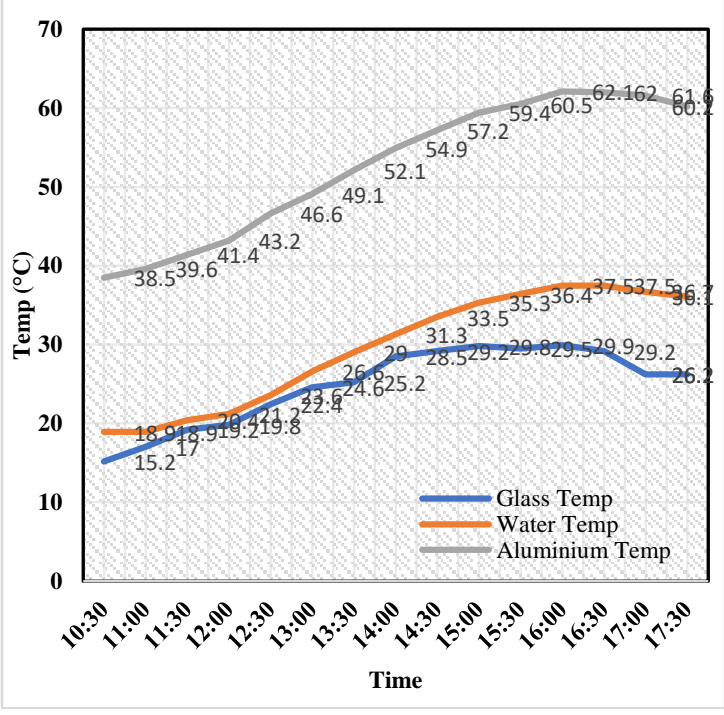

Figure 3. The temperature of Glass, water and Aluminium sheet with respect to time for the $2^{\text {nd }}$ day of the experiment

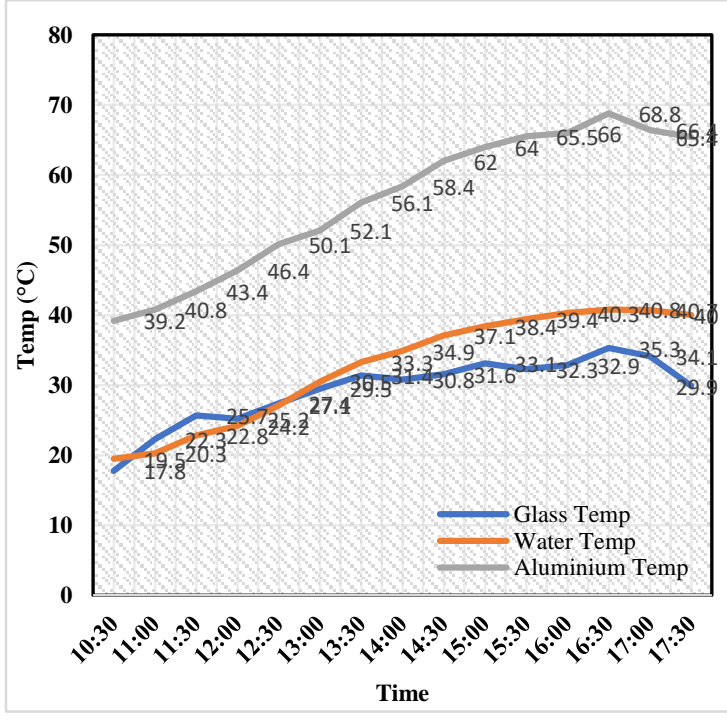

Figure 4. The temperature of Glass, water and Aluminium sheet with respect to time for the $3^{\text {rd }}$ day of the experiment 


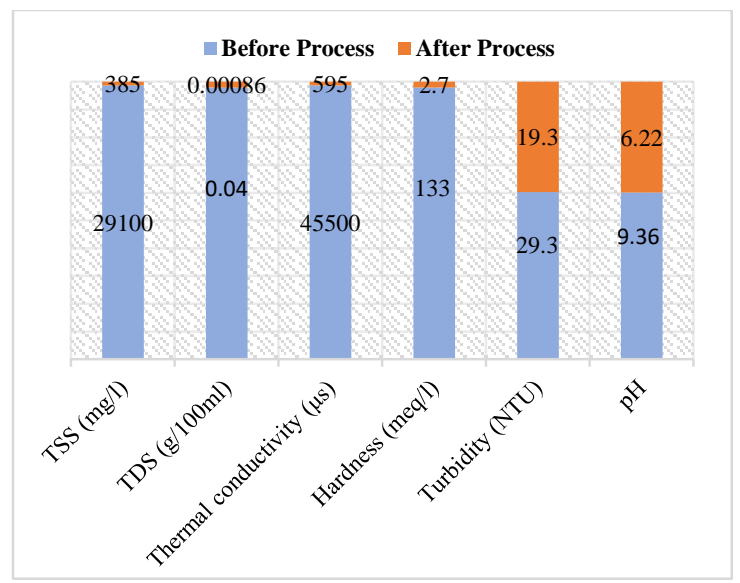

Figure 5. Comparison of different parameters before and after the desalination using single slope solar still

Figure 5 shows the water quality before and after desalination, it can be seen on the graph, a sudden decrease in TSS and the thermal conductivities of the water sample. The figure indicates the performance of a solar plant which not only removes salt contents of the water samples it can also minimize other associated components.

\section{CONCLUSIONS}

Solar desalination unit prepared not only removes salt but it can de-ionize water too for the laboratory purpose or to be used for battery applications. Besides desalination applications, this solar desalination unit can further be utilized as solar a water condenser for humidified air in dual mode. Surface area and material type can further be reassessed and modified to increase the heating rate of the system. It can be helpful for military personals to get potable water during their duties in remote areas. The ease of operation and inexpensive material of manufacture made this solar still a very useful technology to be used efficiently in coastal areas for domestic water purification.

\section{REFERENCES}

[1] N. Khatri and S. Tyagi, "Influences of natural and anthropogenic factors on the surface and groundwater quality in rural and urban areas," Front. Life Sci., vol. 8, no. 1, pp. 23-39, 2015.

[2] G. M. Cappelletti, "An experiment with a plastic solar still," Desalination, vol. 142, no. 3, pp. 221-227, 2002.

[3] UNDP, "The Vulnerability of Pakistan's Water Sector to the Impacts of Climate Change: Identification of Gaps and Recommendations for Action," 2017.

[4] M. K. Daud et al., "Drinking Water Quality Status and Contamination in Pakistan," vol. 2017, 2017.

[5] A. L. Arain, "Assessment of Source and Quality of Drinking Water in Coastal Area of Badin , Sindh , Pakistan," vol. 9, no. 1, pp. 9-15, 2015.

[6] N. Sayied, "The Maritime Commons : Digital Repository of the World Environmental issues in coastal waters Pakistan as a case study," 2007.
I. Zahid, Asadullah, S. Hussain, N. Malghani, Z. Naeem, Saddam, M. Siddique, A. Amin, F. Mushtaq, Waqas, A. Anwer.E. Kakar, "MUNICIPAL WASTEWATER TREATMENT USING RICE HUSK AND KIKAR," in nternational Research Symposium on Engineering Advancements 2016 (IRSEA 2016) SAITM, Malabe, Sri Lanka, 2016, no. June.

[8] T. Authors, W. Science, and W. Supply, "Rainwater harvesting as an alternative for water supply in regions with high water stress Miguel Ángel López Zavala , Mónica José Cruz Prieto and Cristina,” pp. 1946-1955, 2018.

[9] P. Fahmida and A. Sultana, "Desalination Technologies for Developing Countries: A Review Desalination Technologies for Developing Countries: A Review," no. January, 2018.

[10] A. Abusam, "Reuse of greywater in Kuwait," Int. J. Environmnetal Stud., vol. 65, no. 1, pp. 103-108, 2008.

[11] G. Zaragoza, J. A. Andrés-Mañas, and A. Ruiz-Aguirre, "Commercial scale membrane distillation for solar desalination," npj Clean Water, vol. 1, no. 1, pp. 1-6, 2018

[12] H. Chang, C. L. Chang, C. Y. Hung, T. W. Cheng, and C. D. Ho, "Optimization Study of Small-Scale Solar Membrane Distillation Desalination Systems (sSMDDS)," Int. J. Environ. Res. Public Health, vol. 11, no. 11, pp. 12064-12087, 2014

[13] F. Wang, S. Wang, J. Li, D. Xia, and J. Liu, "Seawater desalination with solar-energy-integrated vacuum membrane distillation system," J. Water Reuse Desalin., vol. 7, no. 1, pp. 16-24, 2017.

[14] M. K. Gnanadason, P. S. Kumar, G. Sivaraman, and J. E. S. Daniel, "Design and Performance Analysis of a Modified Vacuum Single Basin Solar Still," Smart Grid Renew. Energy, vol. 02, no. 04, pp. 388-395, 2011.

[15] H. Sharon and K. S. Reddy, "A review of solar energy driven desalination technologies," Renew. Sustain. Energy Rev., vol. 41, pp. 1080-1118, 2015.

[16] H. Jafari Mosleh, S. J. Mamouri, M. B. Shafii, and A. Hakim Sima, "A new desalination system using a combination of heat pipe, evacuated tube and parabolic through collector," Energy Convers. Manag., vol. 99, pp. 141-150, 2015.

[17] F. M. Abed, "Design and Fabrication of a Multistage Solar Still With Three Focal Concentric Collectors," J. Sol. Energy Eng., vol. 140, no. 4, p. 041003, 2018.

[18] O. A. Hamed, H. Kosaka, K. H. Bamardouf, K. Al-Shail, and A. S. Al-Ghamdi, "Concentrating solar power for seawater thermal desalination," Desalination, vol. 396, pp. 70-78, 2016. 